G. Moldabayeva ${ }^{1}$, orcid.org/0000-0001-7331-1633,

R. Suleimenova ${ }^{1}$, orcid.org/0000-0001-7995-5560, N. Buktukov', orcid.org/0000-0001-6370-8557, M. Mergenov ${ }^{3}$, orcid.org/0000-0001-7418-6993
1 - Satbayev University, Almaty, the Republic of Kazakhstan, e-mail: g.moldabayeva@ust-hk.com.cn

2 - D. A. Kunayev Mining Institute, Almaty, the Republic of Kazakhstan

3 - Southern Alberta Institute of Technology, Calgary, Canada

\title{
IMPROVEMENT OF OIL FIELD DEVELOPMENT USING ENHANCED OIL RECOVERY METHODS
}

Purpose. To develop a technology to increase the oil recovery of formations using injection of polymer compositions.

Methodology. For this study, practical methods were used such as enhanced oil recovery using stimulating technologies, technology using polymer systems based on a water-soluble polymer acrylamide, and emulsion-polymer technology. To achieve the conformance control, which was a prerequisite for testing, a thorough selection of wells was carried out, as well as an analysis of their hydrodynamic connection.

Findings. As a result of using the method for limiting water inflows in the development of oil-bearing formations, redistribution of filtration channels, and a decrease in the production of fossil water as well as stabilisation of water cut were achieved.

Originality. The scientific novelty of the study is the withdrawal of wells that are able to redistribute the volume of water injection at perforation intervals. Increased sweep efficiency and pressure at the wellhead at the beginning and at the end of the conformance control indicate a decrease in the conductivity of high-permeability formation intervals.

Practical value. Application of the proposed technology for limiting water inflows will make it possible to develop low-permeability interlayers with filtration flows. The wells brought to a stable production rate during the study will ensure a decrease in formation water production and the water cut of the produced products, as well as stabilisation of the water cut over a certain period.

Keywords: reservoir, production well, water injection well, formation water, oil deposits

Introduction. Oil is one of the key and most valuable minerals in the world. Over the past few years, oil production has increased by more than 20 times, and every year new abundant fields are being commissioned [1]. Basically, oil fields are located in remote and sparsely populated areas, places of occurrence of age-old rocks, on the continental shoals of the seas and oceans.

According to the latest IEA (International Energy Agency) World Energy Outlook report [1], a significant share of fossil fuels in the global energy balance will remain for the next several decades as renewables are not yet sufficiently developed to meet global energy needs. The still quite high demand for fossil fuels [2] requires efficient oil production. As oil wells age, it becomes more difficult and more expensive to continue pumping oil at an economically viable rate, and the problem is exacerbated by the continued decline in hydrocarbon prices [3]. Consequently, there is an ongoing need to develop improved oil recovery techniques.

In addition, the methods of equipment for oil production and refining are being modernised. Often oil deposits have gas caps, in which case the type or field is determined by the significance of the reserves of one of these components. Oil together with water is contained in a branched system of pores, voids, pore channels, cracks, cavities between individual grains or aggregates of rock grains, which is called an oil reservoir [3]. The presence of voids in an oil reservoir is called porosity. Porosity decreases with increasing rock depth.

Literature review. Oil exists in small pores and narrow cracks in the reservoir rock body below the earth's surface. The natural pressure of the reservoir forces oil to rise to the surface, in the case of the existence of a corresponding channel, often such a channel is created by drilling a well from the surface; however, natural oil outcrops to the surface are known in history. However, as oil production progresses, reservoir pressure decreases to a point where artificial lift or pumping is required to maintain an economical rate of oil production [4]. At this stage, secondary production may be required to achieve additional oil production, which includes the use of external energy sources.

(C) Moldabayeva G., Suleimenova R., Buktukov N., Mergenov M., 2021
Additional energy can be introduced by gas injection (gas injection) and/or water (water flooding) [5]. In particular, during water flooding, water is injected into a subterranean oil reservoir with the aim of displacing crude oil from the pore space of a formation rock towards the production wells. Water is usually pumped into a series of wells or one auxiliary well surrounding a central production well, then collected, filtered and recirculated. This cyclical pattern of water injection and residual oil production can be repeated throughout the entire reservoir.

Primary production usually results in an average production of only a fraction of the oil originally present in the reservoir. Secondary recovery, such as water flooding, usually recovers some more percent of the hydrocarbon reserves, resulting in a good industry example of $33 \%$ of the final recovery [6], by the time continuation becomes unprofitable. Therefore, it is not unusual that 60 to $70 \%$ of the oil being initially in the reservoir remains even after the completion of secondary production, these numbers can be called the economic limit for traditional recovery technologies.

Two main factors contribute to the fact that the unrecovered oil remains in the reservoir. The first factor is capillary forces arising from high oil/water interfacial tension [7]. This problem can be addressed by techniques such as gas flooding (e.g. $\mathrm{CO}_{2}$ or $\mathrm{N}_{2}$ [8] or chemicals (e.g. alkali or surfactant flooding) [9]. In addition, when there is highly viscous heavy oil in a subterranean formation, flooded water tends to bypass significant parts of the formation due to its mobility and low viscosity [10] This can be addressed by increasing the viscosity of the injected water, which is often achieved using materials such as water soluble or water dispersible removable polymers with high molecular weight [11]; however, adverse environmental conditions in the subterranean formation, such as high temperature and dissolved electrolytes, can cause some polymers to precipitate and/or lose their viscosity-increasing efficiency, thereby again increasing flood water mobility.

The issue of permeability in the reservoir should be considered a substantial circumstance that is one of the causes of oil waste pollution [12], as it leads to weakening of the flow and occurrence of residual phenomena. Permeability refers to the 
ability of a solid to pass a fluid flow. Permeability is considered high when the fluid flow is relatively free. In all other cases, there is no question of good permeability indicators. The permeability of materials in the reservoir, as a rule, may vary, which causes significant problems. Oil and water tend to pass through some layers much more easily than others, simply because the physical composition of the formation differs depending on oil production methods. If a formation comprising several layers with different permeability is involved in the process, water mainly fills thick zones with higher permeability, without entering thin zones where the permeability is much lower. It has been observed that the permeability of the zones increases as the water passing through them pushes the oil out $[13,14]$.

Ultimately, zones with higher permeability are exposed to more intense water, which pushes oil, while zones of low permeability receive substantially less water. The result is an intense displacement of oil from areas with higher permeability, while in areas of low permeability, oil is retained. The most rational way out of the situation is to mainly pump water into zones where the permeability index is lower. In practice, there are numerous methods for water distribution in these zones [15].

The purpose of the study is to develop an enhanced oil recovery technology using polymer injection.

Development of a technology of enhanced oil recovery. The essence of the technology proposed is to isolate the existing system of man-made cracks in the bottom-hole zone and regulate the profile of injectivity and filtration flows in heterogeneous fractured-porous formations of an injection well. The viscoelastic properties of the polymer system in reservoir conditions are realised in the form of a residual resistance factor (decrease in water mobility), as well as a limiting pressure gradient. The rheological properties of the high molecular weight composition based on $\mathrm{AN}-132$ provide high filtration selectivity in a layered heterogeneous formation.

The technology for limiting water inflows will provide:

1. Redistribution of filtration flows with connection to the development of low-permeability interlayers in the oil-saturated part of the formation.

2. Decrease in water cut of produced products.

3. Decrease in formation water production.

4. Stabilisation of the water cut at the achieved level for a certain period.

Materials and methods. The use of technologies that stimulate the extraction is possible, including in the presence of a hydrodynamic connection between layers. The fluids fill the interlayers and thereby create waterproofing in the formation, which helps to direct water flows to the production well and thereby increase additional oil flow.

To align the injectivity profile and regulate the waterflooding process in the well, a technology is proposed using polymer systems based on a water-soluble polymer of acrylamide grade AN-132. Approbation of the proposed approach is envisaged at the Kumkol field (Kyzyl - Orda region of the Republic of Kazakhstan), the test program provides for the injectivity profile alignment (IPA). The tests were carried out on 7 wells; all 7 wells achieved the expected effect. Criteria for selection of wells for pilot drilling by drilling perforation: oilsaturated formations with bottom water; formations with weak boundaries; selective opening of productive formations, thin oil formations, interlayers; cementing of poor quality, in the area of the productive formation; penetration of perforations beyond the clogging zone (with a large positive skin factor).

Field of application, type of reservoir is terrigenous-porous. Productive formations - chalk deposits. All wells tested were in chalk deposits. They are represented by sandstones and clayey sandstones, characterised by alternating layers with medium and high porosity and permeability. Artificial bottom-hole - $1330 \mathrm{~m}$, current bottom - $1291.5 \mathrm{~m}$. Accumulated injection is $4056344 \mathrm{~m}^{3}$ of water. The study of the IPA at the Kumkol field began in 2010; the IPA is being carried out using polymer emulsion technology. The purpose of this technology is to increase the current and final oil recovery factor by levelling the heterogeneity of the productive formation, increasing the coverage of the formation by waterflooding and redistribution of flows in the formations due to a decrease in the permeability of the most permeable intervals and the involvement of low-permeability zones.

The emulsion-polymer technology is based on the use of crosslinked polymer systems based on water-soluble polymers of acrylamide grade AN-132 together with chromium acetate, as well as a hydrophobic emulsion with a filler, which is prepared based on Cleave emulsifier, as a filler fine rubber crumb is used. The hydrophobic emulsion with a filler acts as a primary filtration resistance, filling cracks and "super conductive channels" resulting from significant bottom-hole pressures in the injection well. The main stages of the technological process:

1) preparation of inverse emulsion based on the Cleave emulsifier;

2) introduction of the filler into the inverse emulsion;

3 ) injection of reverse emulsion with filler into the well;

4) injection of a working polymer solution into the well;

5) squeezing the working solution with the calculated amount of technical liquid

6) exposure to gelation;

7) well is put in operation.

To study the runway operation, the selection of wells for the runway was carried out, the analysis of the operation of the reacting wells (advanced watering in the area compared to the main stock); the results of FGT on injection wells (uneven well injectivity profile, low coverage of the reservoir by injection); well correlations - tracking interlayers along the reacting wells (hydrodynamic connection).

Results. Below are the main results of waterflooding at the Kumkol field. The choice of this deposit is not accidental:

1. The reservoir of an oil-saturated field is heterogeneous in terms of the permeability of the medium.

2. Oil fields have been considerably depleted for a long time, which is reflected in the characteristics of the reservoirs. This causes the heterogeneity of the collector systems.

3. The waterflooding system used today for the main development facility is based on the principle of a four-point (seven-point recalculation) system for the location of production and injection wells, each of which is located in the centre of a regular hexagon. Furthermore, each production well is located in the centre of a triangle formed by water supply wells.

4. Production wells were gradually flooded due to the filling of the main reservoir with water. This creates the need for non-stationary waterflooding. The Kumkol field also contains layers of oil-saturated limestone.

The field is characterised by thick oil with high viscosity. The main horizon includes two oil-saturated reservoirs. The separation of reservoir and bottomhole pressures for the operating producing wells suggests that half of the wells operate with reservoir and bottomhole pressures at a level substantially lower than the oil and gas saturation pressure parameter. Despite the fact that the accumulated compensation of fluid production by water injection at both operating facilities reached $77-78 \%$, the location of the bulk of the wells in the areas indicates low water injection rates. In formations that were perforated not in injection, but in production wells, the formation pressure decreases below the oil and gas saturation pressure, and this is the reason for the productivity decrease in these formations in comparison with the perforated ones, which explains the acceleration of water penetration through the perforated layers.

Analysis of the effectiveness of the work performed. Since January 2011, efficiency has been calculated from the displacement performance in the BASPRO program. For the calculations, 7 characteristics of oil drive were selected: the Pirverdyan, Kambarov, Multiparametric, Exponential, Sazonov, Naz- 
arov-Sipachev methods. For each of the methods, the correlation coefficient of the displacement model with the base period was determined. The Kambarov method has the highest correlation coefficient -0.6 (Table 1 ).

When calculating the efficiency of the IPA of an intake well, the maximum values of the increase and loss for various displacement characteristics are not taken into account.

Consider the map of the current production of the YuI-II object for I injection site (wells 2227, 2199, 2197d) in Table 2. Since the completion of work on the IPA, from the surrounding/observation wells, well 2180 was taken - workover plans.

At the present time, according to the Kambarov method, we observe the completion of the runway effect in this section. The duration of the effect was 3-4 months. It is necessary to carry out a repeated set of works on the runway of the injection wells of the area with the separation of measures in time to determine the effective and ineffective runways. The type of the diagram depends on which and how many tools were lowered into the well.

Geophysical well survey (GIS) is a complex of methods of exploration geophysics. They are used to study the properties of rocks in the near-wellbore and interwell spaces, as well as to monitor the technical condition of wells. Well logging is divided into two groups: logging and downhole geophysics. Well logging is performed to study the geological structure of the section, identify productive formations (primarily for oil and gas), and determine the reservoir properties of formations.

The geophysical survey is used for:

1) to control the quality of cementing and well profile;

Table 1

Oil drive methods

\begin{tabular}{|l|c|}
\hline \multicolumn{1}{|c|}{ Oil drive characteristics } & Correlation coefficient \\
\hline Kambarov & 0.64 \\
\hline Inverse & 0.636 \\
\hline Exponential & 0.632 \\
\hline Nazarov-Sipachev & 0.63 \\
\hline Pirverdyan & 0.614 \\
\hline Sazonov & 0.53 \\
\hline Multiparametric & 0.44 \\
\hline
\end{tabular}

Table 2

Oil drive methods for wells 2197d, 2227, 2199 (calculated using the BASPRO program)

\begin{tabular}{|l|c|}
\hline \multicolumn{3}{|c|}{ Wells 2197d, 2227, 2199 } \\
\hline \multicolumn{3}{|c|}{ Sazonov method Increase } \\
\hline 2 object & 482.7 \\
\hline \multicolumn{3}{|c|}{ Pirverdyan method } \\
\hline 2 object & 4797.4 \\
\hline \multicolumn{3}{|c|}{ Inverse method } \\
\hline 2 object & 9576.9 \\
\hline \multicolumn{3}{|c|}{ Nazarov-Sipachev method } \\
\hline 2 object & 9318.7 \\
\hline \multicolumn{3}{|c|}{ Exponential method } \\
\hline 2 object & 4283.1 \\
\hline \multicolumn{3}{|c|}{ Multiparametric method } \\
\hline 2 object & -22067.2 \\
\hline \multicolumn{3}{|c|}{ Kambarov method } \\
\hline 2 object \\
\hline
\end{tabular}

2) to obtain information about the geological section as a whole and a more detailed study on the characteristics of the productive formation;

3) to tie the well to the geological section;

4) for orienting the whipstock during sidetracking.

GIS on pipes, unlike cable, is autonomous. The bottom line is that the sensors are descended together with the batteries; the descent is carried out on drill pipes. It is calculated in what time these devices will be lowered to the set depth and a timer is set relative to this, after which the device will start recording. The complex is registered, it rises and is disassembled, information is read out and everything is also interpreted.

The black line in Figs. 1-5 denotes oil debit; green - base oil debit; red - water cut; blue - basic water cut. According to the field geophysical tests data in Figs. 1 and 2, there is a redistribution of the injection volumes over the well perforation intervals, which indicates a decrease in the conductivity of the washed and highly permeable formation intervals. The wellhead pressure at the beginning and end of the IPA increased from 80 to 95 atm

According to the field geophysical tests data in Figs. 3 and 4, there is a redistribution of injection volumes by perforation intervals, the injection sweep ratio increased from 43.3 to $53.2 \%$, which indicates a decrease in the conductivity of high-permeable intervals of the formation. The wellhead pressure at the beginning and end of the IPA increased from 60 to $85 \mathrm{~atm}$.

According to the field geophysical tests data in Fig. 5, there is a redistribution of injection volumes over the perforation intervals and an increase in the Y1 sweep efficiency from 26.4 to $42.7 \%$, which indicates a decrease in the conductivity of the washed and high-permeable intervals of the formation. The

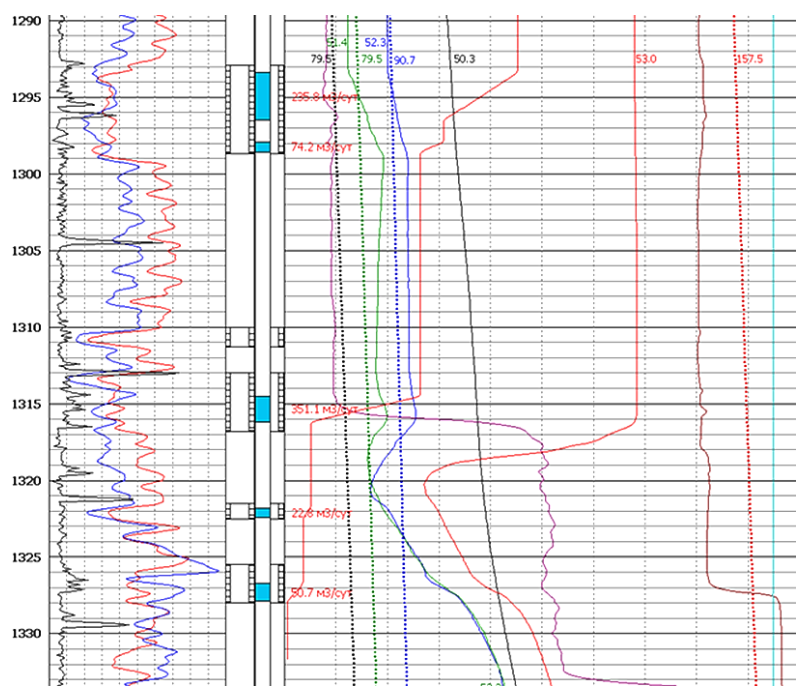

Fig. 1. Well 2227, Kumkol, formation YuI-II. GWL before IPA of 05.06 .2018

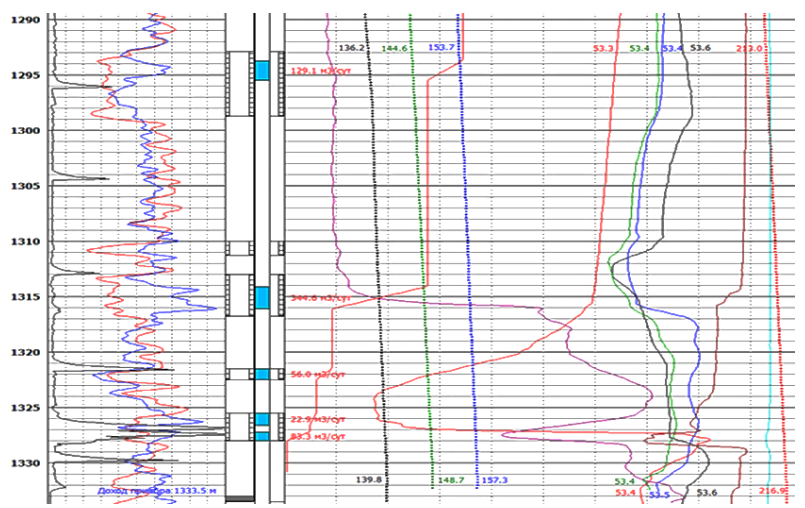

Fig. 2. GWL after IPA of 12.07.2018 


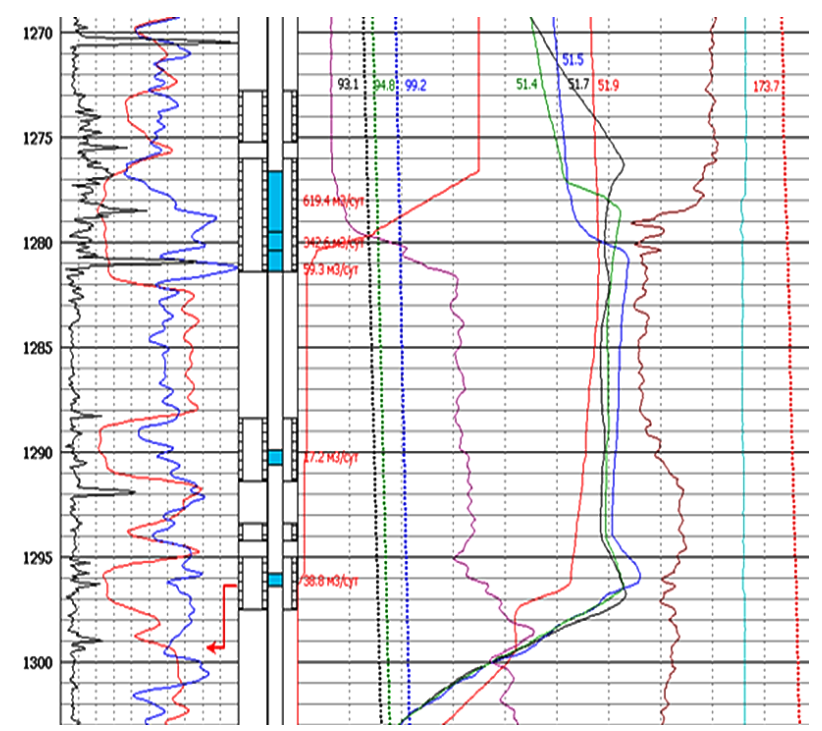

Fig. 3. Well 2197d, Kumkol, formation YuI-II. GWL before IPA of 25.09.2017

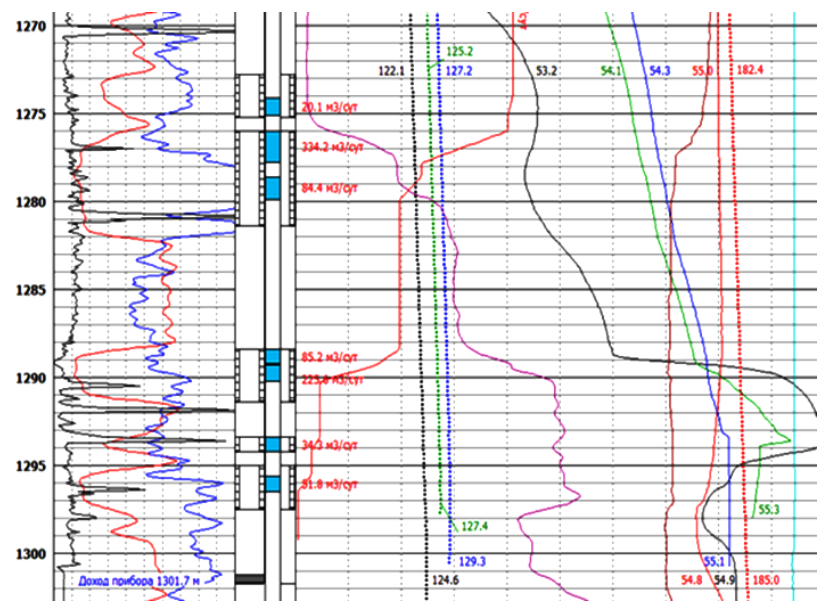

Fig. 4. GWL after IPA of 02.08.2018

wellhead pressure at the beginning and end of the IPA increased from 65 to $95 \mathrm{~atm}$. After the completion of work on the IPA, from the surrounding/observation wells well 3073 was taken - workover plans.
At certain stages of the development of the filtration process, it is possible to describe and predict the further development of this process using the presented models. These models are presented in terms of the main characteristics of displacement. The low results for some wells can be explained by the fact that one has to deal with objects with low-activity waters (when the object works to deplete reservoir energy or when the water cut level is kept at low values) [16, 17]. The same applies to facilities where work is being actively carried out to reduce the water cut of well production [18]. Since these methods are very sensitive to all kinds of adjustments to the operating mode of the object.

Well 2127 can be cited as an example. Currently, there is no effect from the IPA (Fig. 6). The reason is the location of well 2127 in the border zone - the effect of the IPA is distributed to the PKKR wells. Well 3073 was also withdrawn from the reacting well stock due to workover plans. It is necessary to conduct a repeated GIS-K to determine the need for a repeated IPA. According to field geophysical tests, there is a redistribution of injection volumes by perforation intervals, an increase in the injection coverage ratio from 22.8 to $48.5 \%$, which indicates a decrease in the conductivity of the washed and highly permeable formation intervals. The wellhead pressure at the beginning and end of the IPA increased from 65 to $95 \mathrm{~atm}$

In the world practice, subsequent to extensive scientific research, polymer flooding was introduced on an industrial scale in many areas, which made it the main technology for oil production in industrial fields with a high permeability index and an average level of permeability. It is believed that apart from reducing the value of water-to-oil mobility, polymer flooding can also increase the displacement of water from oil.

The other properties contribute to displacement, as force indicators must also be considered, because it leads to deformation of the oil and the elimination of the oil film.

Polymer products of different molecular weights and structure were introduced [19]. Optimisation schemes have been developed, including for injection of individual layers differing in molecular weight. Theoretical and technological studies have further increased the efficiency of polymer flooding $[19,20]$. In the initial commercial period, this technology has increased the recovery rate by $12 \%$ from about $8 \%$. Polymer flooding faces big challenges today, mainly including limitation of the displacement mechanism, small incremental oil recovery, high polymer utilisation, rapid increase in water cut and decreased production after polymer flooding, dispersed distribution of the remaining oil after
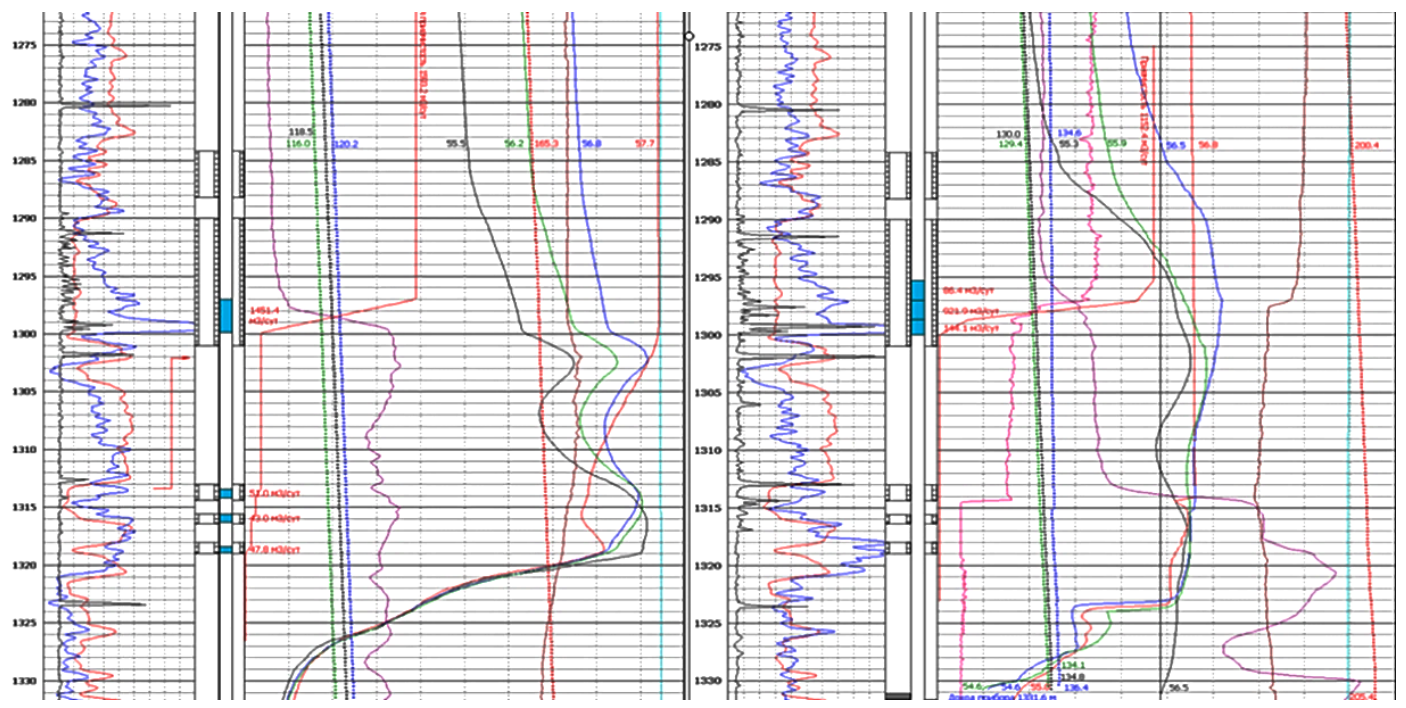

Fig. 5. Well 2199, Kumkol, formation YuI-II. GWL before IPA of 19.06.2017 - GWL after IPA of 22.09.2017 


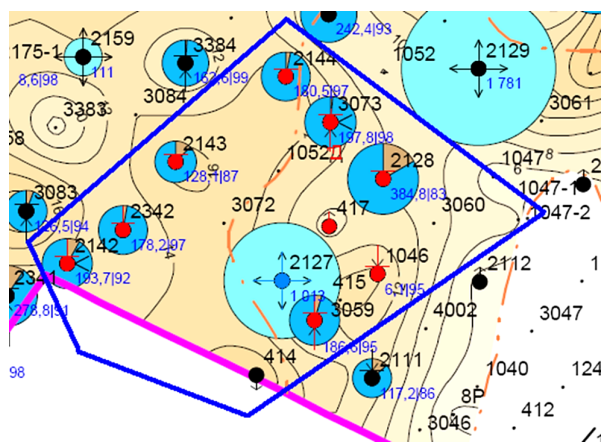

Fig. 6. Map of current production of the YuI-II object for the injection section of well 2127

polymer flooding, and lack of effective technology replacement. Therefore, the functional polymer technology should be improved, and the design for polymer flooding and enhanced oil recovery technology after polymer flooding should be optimised.

Conclusions. The proposed approach to limiting water inflows in the development of oil-bearing formations will ensure the redistribution of filtration flows with connection to the development of low-permeability interlayers in the oilsaturated part of the formation; decrease in water cut of the produced products; reduction in formation water production; stabilisation of water cut at the achieved level for a certain period.

According to the IPA, the additional production was, according to various assessment methods, from 6290 to 12072 tons. The greatest effect was obtained for the wells of the II production facility. Additional production from wells of object II was 4328 tons (average value for 5 displacement characteristics). For wells of object III, the increase was 1962 tons.

Evaluation of the IPA efficiency and the final result is significantly influenced by the conduct of geological and technical measures on the reacting wells and the need to exclude such wells from the evaluation. As a result of geological and technical measures, from 7 to $28 \%$ of reacting wells in various areas were excluded from the calculation of efficiency. New wells commissioned during the runway effect observation period were not taken into account.

\section{References.}

1. International Energy Agency (2019). World Energy Outlook 2019 report. Retrieved from: https://www.iea.org/reports/world-energyoutlook-2019.

2. Le Billon, Ph., \& Kristoffersen, B. (2020). Just cuts for fossil fuels? Supply-side carbon constraints and energy transition. Environment and Planning A: Economy and Space, 52(6), 1072-1092. https://doi. org $/ 10.1177 / 0308518 X 18816702$.

3. Kukhtin, P., \& Znamenskaya, E. (2019). New challenges for the development of the oil market. E3S Web of Conferences, 135, 04060. https://doi.org/10.1051/e3sconf/201913504060.

4. Akchiche, M., Beauquin, J-L., Serra, S., \& Sochard, S. (2020). Exergoeconomic Optimization of Oil and Gas Production Systems. In: SPE Europec Featured at 82 $2^{\text {nd }}$ EAGE Conference and Exhibition, (pp. 1-15). https://doi.org/10.2118/200607-MS.

5. Altunina, L. K., Kuvshinov, V.A., \& Kuvshinov, I.V. (2019). Enhanced oil recovery technologies for Arctic and Siberian regions. IOP Conference Series: Materials Science and Engineering, 696(1), 1-7. https://doi.org/10.1088/1757-899X/696/1/012001.

6. Das, A., Nguyen, N., \& Nguyen, Q.P. (2020). Low-tension gas flooding for secondary oil recovery in low-permeability, high-salinity reservoirs. Fuel, 264, 116601. https://doi.org/10.1007/s12182-02000455-9.

7. Panda, A., Pati, A. R, Saha, B., Kumar, A., \& Mohapatra, S. S. (2019). The role of viscous and capillary forces in the prediction of critical conditions defining super-hydrophobic and hydrophilic characteristics. Chemical Engineering Science, 207, 527-54. https://doi. org/10.1016/j.ces.2019.06.013.
8. Drexler, S., Correia, E.L., Jerdy, A.C., Cavadas, L.A., \& Couto, P. (2020). Effect of $\mathrm{CO}_{2}$ on the dynamic and equilibrium interfacial tension between crude oil and formation brine for a deepwater Pre-salt field. Journal of Petroleum Science and Engineering, 190, 107095. https://doi.org/10.1016/i.petrol.2020.107095.

9. Bahraminejad, H., Manshad, A. K., Ali, J. A., \& Riazi, M. (2019) $\mathrm{CuO} / \mathrm{TiO}_{2} / \mathrm{PAM}$ as a novel introduced hybrid agent for water - oil interfacial tension and wettability optimization in chemical enhanced oil recovery. Energy \& Fuels, 33(11), 10547-10560. https://doi. org/10.1021/acs.energyfuels.9b02109.

10. Guo, K., Hailong, L., \& Zhixin, Yu. (2016). In-situ heavy and extra-heavy oil recovery: A review. Fuel, 185, 886-902. https://doi. org/10.1016/j.fuel.2016.08.047.

11. Gómez-Jaimes, F. N., Blanco-Tirado, C., \& Combariza, M.Y. (2020). Amidated cellulose nanofibrils as demulsifying agents for a natural water-in-heavy-crude-oil emulsion. Energy \& Fuels, 34(11), 14012-14022. https://doi.org/10.1021/acs.energyfuels.0c02790. 12. Javaheri, A., Habibi, A., Hassan, D., \& Wood, J. M. (2018). Imbibition oil recovery from tight rocks with dual-wettability behavior Journal of Petroleum Science and Engineering, 167, 180-191. https:// doi.org/10.2118/185076-MS

13. Yong, L., Song, B., Baozhu, L., Changbing, T., Yixiang, Z., \& Quihao, Q. (2017). Representative sector modeling and key factors impact on waterflooding performance of a large multi-layered sandstone reservoir. In: SPE Europec Featured at $79^{\text {th }}$ EAGE Conference and Exhibition. Society of Petroleum Engineers, (2014), (pp. 1378-1392). https://doi.org/10.2118/185856-MS

14. Konwar, L., Aiowainati, E., Nemmavi, N., Michael, D., \& Ali, A (2020). Understanding mauddud waterflood performance in a heterogeneous carbonate reservoir with surveillance data and ensemble of analytical tools. In: Abu Dhabi International Petroleum Exhibition \& Conference. Society of Petroleum Engineers, (2020), (165204). https:// doi.org/10.2118/202798-MS

15. Song, X., \& Yong, L. I. (2018). Optimum development options and strategies for water injection development of carbonate reservoirs in the Middle East. Petroleum Exploration and Development, 45(4), 723734. https://doi.org/10.1016/S1876-3804(18)30075-2.

16. Kairbayeva, A., Vasilenko, V., Dzhinguilbayev, S., Baibolova, L., $\&$ Frolova, L. (2018). Development of the mathematical model for the process of oil raw materials pressing. International Journal of Engineering and Technology (UAE), 7, 145-149. https://doi.org/10.36478/jeasci. 2017.7836 .7842 .

17. Ciolkosz, D., Kukharets, S., \& Tripath, J. (2020). Torrefied biomass in biofuel production system. Scientific Horizons, 8(93), 9-12. https://doi.org/10.33249/2663-2144-2020-93-8-9-12.

18. Kartskhiya, A.A., Tyrtychnyy, S.A., Smirnov, M. G., \& Dolgikh, M. G. (2021). Formation of the Russian oil industry in the $19^{\text {th }}$ century: Historical experience and modern assessments. Bylye Gody, 58(4), 2471-2484. https://doi.org/10.13187/BG.2020.4.2471.

19. Yang, H., Iqbal, M. W., \& Lashari, Z. (2019). Experimental research on amphiphilic polymer/organic chromium gel for high salinity reservoirs. Colloids and Surfaces A: Physicochemical and Engineering Aspects, 582, 123900. https://doi.org/10.1016/i.colsurfa.2019.123900.

20. Sun, C., Guo, H., Li, Y., \& Song, K. (2020). Recent advances of surfactant-polymer (SP) flooding enhanced oil recovery field tests in China. Geofluids, 4, 1-16. https://doi.org/10.1155/2020/8286706.

\section{Удосконалення розробки нафтових родовищ з використанням методів збілышення нафтовіддачі}

\section{Г. Молдабаєва ${ }^{1}$, Р. Сулейменова ${ }^{1}$, М. Буктуков ${ }^{2}$, М. Мергенов ${ }^{3}$}

1 - Satbayev University, м. Алмати, Республіка Казахстан, e-mail: g.moldabayeva@ust-hk.com.cn

2 - Інститут гірничої справи імені Д. А. Кунаєва, м. Алмати, Республіка Казахстан

3 - Технологічний інститут Південної Альберти, м. Калгарі, Канада

Мета. Розробка технології підвищення нафтовіддачі пластів з використанням нагнітання полімерних композицій. 
Методика. Для даного дослідження використовувалися такі практичні методи, як: збільшення нафтовіддачі за допомогою стимулюючих технологій, технологія з використанням полімерних систем на основі водорозчинного полімеру акриламіду, емульсійно-полімерна технологія. Для досягнення вирівнювання профілю прийомистості, що було обов'язковою умовою дослідження, проводився ретельний відбір свердловин, а також аналіз їх гідродинамічного зв'язку.

Результати. У результаті застосування методу обмеження надходження води при розробці нафтоносних формацій, були досягнуті перерозподіл каналів фільтрації, зниження видобутку пластової води, а також стабілізація обводнення.

Наукова новизна. Науковою новизною дослідження є виведення свердловин, що здатні перерозподіляти обся- ги закачування води за інтервалами перфорації. Збільшений коефіцієнт охоплення закачуванням і тиск на гирлі на початку та в кінці вирівнювання профілю прийомистості свідчать про зниження провідності високопроникних інтервалів пласта.

Практична значимість. Застосування запропонованої технології обмеження надходження води дозволить розробити низькопроникні пропластки з фільтраційними потоками. Виведені у ході дослідження свердловини забезпечать зниження видобутку пластової води та обводнення продукції, а також стабілізацію обводнення протягом певного періоду.

Ключові слова: колектор, видобувна свердловина, водонагнітальна свердловина, пластова вода, нафтові поклади

The manuscript was submitted 02.03.21. 